\title{
Chemical composition and bioactive compounds of grape pomace (Vitis vinifera L.), Benitaka variety, grown in the semiarid region of Northeast Brazil
}

Eldina Castro SOUSA ${ }^{1 *}$, Ana Maria Athayde UCHÔA-THOMAZ ${ }^{1}$, José Osvaldo Beserra CARIOCA², Selene Maia de MORAIS ${ }^{3}$, Alessandro de LIMA ${ }^{1}$, Clécio Galvão MARTINS ${ }^{3}$, Cristiane Duarte ALEXANDRINO³, Pablito Augusto Travassos FERREIRA³, Ana Livya Moreira RODRIGUES 3 , Suliane Praciano RODRIGUES 3 , Jurandy do Nascimento SILVA ${ }^{1}$, Larissa Lages RODRIGUES ${ }^{1}$

\begin{abstract}
Grape pomace (Vitis vinifera L.), Benitaka variety, grown in the semiarid region of Northeast Brazil was evaluated in relation to chemical composition, and content of minerals and functional properties. Its microbiological quality and toxic potential, using Artemia salina sp, were also investigated. The results showed that the flour obtained from these residues had below neutral $\mathrm{pH}$ (3.82), moisture $(3.33 \mathrm{~g} / 100 \mathrm{~g})$, acidity of $(0.64 \mathrm{~g}$ of citric acid $/ 100 \mathrm{~g})$, and ash $(4.65 \mathrm{~g} / 100 \mathrm{~g})$. The amount of total dietary fiber $(46.17 \mathrm{~g} / 100 \mathrm{~g})$ stood out quantitatively compared to the content of carbohydrate $(29.2 \mathrm{~g} / 100 \mathrm{~g})$, protein $(8.49 \mathrm{~g} / 100 \mathrm{~g})$, and lipids $(8.16 \mathrm{~g} / 100 \mathrm{~g})$. The total energy was $224 \mathrm{Kcal} / 100 \mathrm{~g}$. With regard to the compounds with functional properties, higher values of insoluble fiber $79 \%(36.4 \mathrm{~g} / 100 \mathrm{~g})$; vitamin C $(26.25 \mathrm{mg}$ of acid ascorbic/100g), and anthocyanins $(131 \mathrm{mg} / 100 \mathrm{~g})$ were found. The minerals iron, potassium, zinc, manganese, and calcium were present in higher concentrations. There were no significant copper values. The results showed that the grape residues are an important source of nutrients and compounds with functional properties suggesting that they can be incorporated as an ingredient in the diet and/or used as a dietary supplement aiming at health benefits. The residues did not show microbiological contamination and were considered nontoxic.
\end{abstract}

Keywords: grape pomace; chemical composition; minerals; bioactive compounds; microbiological quality; Artemia salina sp.

\section{Introduction}

Because of the beneficial effects on human health and its economic importance, grape is a fruit widely grown and eaten around the world. Historically, the production and export of grapes were controlled almost exclusively by traditional European countries; however, in recent years, South America has shown significant rate of growth in production and export of grapes with two crops a year (Ruiz, 2011). According to data from the Food and Agriculture Organization (2010), Brazil occupies the $20^{\text {th }}$ position in terms of world production of grapes. In 2012, data show that the annual production of grapes in Brazil ranged from 1.3 and 1.4 million tons/year (Camargo et al., 2011; Instituto Brasileiro de Geografia e Estatística (2013).

Municipalities in the Northeast of Brazil, where the predominant climate is semi-arid and dry sub-humid, are characterized by low rainfall and relative and high air temperature and solar radiation (Andrade Júnior et al., 2005). Phytosanitary problems tend to be smaller and fruit quality tends to be better, which is essential for the expression of the productive potential of the European vine (Costacurta \& Roselli, 1980; Coombe, 1987). According to the Brazilian Institute of Geography and Statistics, in 2012, the planting of grapes in northeastern Brazil was 9.437 hectares, with total production of 287.050 tons and average yield of $31.043 \mathrm{~kg} / \mathrm{ha}$. In February 2013 , data indicated a $2 \%$ increase in production although a
$0.4 \%$ decrease in the total area planted was observed (Instituto Brasileiro de Geografia e Estatística, 2013). Along with this intensive production, large amounts of agro-industrial residues are generated (Bustamante et al., 2008; Tangolar et al., 2009; Cetin et al., 2011; Deng et al., 2011; Lachman et al., 2013). According to a study conducted in 2011 by the Brazilian Ministry of Environment (Brasil, 2011), the production of grape waste in Brazil was 290.838.411 tons.

The agro-industrial residues of grape are mostly solid byproducts such as stalks, pomace and the liquid filtrate. Depending on the conditions of the grapes when they are harvested, the residues may represent from 13.5 to $14.5 \%$ of the total volume of grapes, and may reach 20\% (Ahmad \& Ali Siahsar, 2011; Rockenbach et al., 2008). These residues are composed of water, proteins, lipids, carbohydrates, vitamins, minerals, and compounds with important biological properties such as fiber, vitamin $\mathrm{C}$, and phenolic compounds (tannins, phenolic acids, anthocyanins, and resveratrol), depending on the type of waste, the cultivar and climatic and cultivation conditions (Ahmad \& Ali Siahsar, 2011; Rockenbach et al., 2007, 2008; Pontes et al., 2010; Burin et al., 2010). Due to the functional properties of these residues, which are capable of acting on the metabolism and human physiology producing beneficial health effects, the extraction of these bioactive substances can provide many 
opportunities for adding value to food products contributing to the improvement of dietary pattern of the population and helping prevent diseases such as cancer, cardiovascular disease, Alzheimer's, and other degenerative diseases, besides decreasing the environmental impact and economic losses (Tangolar et al., 2009; Cetin et al., 2011; Deng et al., 2011; Lachman et al., 2013). However, for better understanding the use and benefits of this plant and its waste, it is necessary to know its chemical constituents and evaluate the risk/benefit ratio of their use through chemical, microbiological, and toxic potential analyses (Devesa-Rey et al., 2011).

The bioassay method using the micro crustacean Artemia salina sp has been used to evaluate the toxicity of plant products; this is simple and low cost method. Although not specific, this method has a good correlation with tumor cells and pesticidal activity (Leite et al., 2009). This bioassay allows the evaluation of overall toxicity, and therefore it is considered the preliminary study of compounds with potential biological activity. Studies on the lethality of Artemia salina sp. in plant extracts have been widely conducted (Araújo et al., 2010; Lachumy et al., 2010; Bussmann et al., 2011; Jiménez et al., 2011).

This paper aimed to characterize grape pomace in terms of chemical composition, mineral content, and functional properties and determine its microbiological quality and toxic potential to evaluate the feasibility of using it in food industries improving the nutritional value of food products and the quality of life of consumers.

\section{Materials and methods}

\subsection{Grape samples' characterization, processing, and flour preparation}

Samples of grape (Vitis vinifera L.) of the variety Benitaka were collected by the authors directly from the Vine Complex at Marrecas settlement (2011/2012 harvest season) in the municipality of São João do Piauí, Piauí state, Northeastern Brazil. After harvest, the grapes were transported in cool boxes to the city of Teresina, capital of the state of Piauí, to the Laboratory of the Federal Institute of Education, Science and Technology of Piauí, Teresina South Zone, where they were stored under refrigeration for 48 hours at $4^{\circ} \mathrm{C}$ until analysis.

Initially, the grapes were weighed and graded according to Normative Instruction No. 01 of 1 February 2000, the Ministry of Agriculture, Livestock and Supply (Brasil, 2000). The grapes used were from Group I (consisting of variety with seed), Subgroup Colorful, Class 2 (mass of clusters between $200 \mathrm{~g}$ and $500 \mathrm{~g}$ ), Division 20 (berries with a caliber greater than or equal to $20 \mathrm{~mm}$ and less than $22 \mathrm{~mm}$ ) and Extra Class (typical coloring, green stems, and no bunch deformation). Then grapes were then cleaned and pressed using an industrial depulper separating the pomace (skin and seeds) and pulp for the extraction of grape juice.

After extraction, the pomace was stored in polyethylene bags at $-18{ }^{\circ} \mathrm{C}$ until processing. The pomace was dried in an air circulation oven (Tecnal, model TE-394/L) at $60{ }^{\circ} \mathrm{C}$ for approximately 16 hours. The dried residue was triturated using a domestic blender (Walita) and a flour was obtained and sieved using a set of seven sieves $(10,30,40,60,80,100$, and 200 mesh corresponding to openings: $2,0.60,0.42,0.25$, $0.18,0.15$, and $0.075 \mathrm{~mm}$, respectively). The flour was packed in lidded polyethylene bottles until analysis. The flour was then subjected to chemical analysis for determination of vitamin $\mathrm{C}$, anthocyanins, minerals, microbiological quality, and toxic potential. Subsequently, from the flour obtained, extractions using different solvents were performed and the extracts were subjected to toxicological analysis.

\subsection{Chemical analysis}

Acidity, $p H$, moisture, and ash

Acidity was determined by titration with $0.1 \mathrm{~N} \mathrm{NaOH}$, and the results were expressed in grams of citric acid/100g. The $\mathrm{pH}$ was determined by direct reading on the potentiometer, (MS Tecnopon, model mPA210) calibrated in buffer solutions of $\mathrm{pH}$ 4.0 and 7.0. Moisture determination was performed by drying the sample in an air circulation oven (Tecnal, model TE-394 /L) at $105^{\circ} \mathrm{C}$ to constant weight. Moisture was calculated by the difference in the mass of the sample before and after drying; the result was expressed in percentage of moisture. Ash was determined by incineration in a furnace at $550^{\circ} \mathrm{C}$ until constant weight. These analyses were performed in triplicate according to the method described by the Adolfo Lutz Institute (2008).

\section{Lipids, protein, total dietary fiber, and total carbohydrate}

Lipids were obtained by Soxhlet extraction using hexane as solvent under reflux for 6 hours, according to the analytical standards of the Adolfo Lutz Institute (2008). Protein was determined by the micro-Kjeldahl method using copper sulphate and selenium as catalysts of mineralization and boric acid as the receiver solution in the distillation of ammonia. Next, the sample was titrated with $0.1 \mathrm{~N}$ hydrochloric acid. The conversion factor of 6.25 was used to covert nitrogen into protein, as recommended by Association of Official Analytical Chemistry (1995). Total dietary fiber (TDF) was obtained by adding the soluble and insoluble fractions, according to the enzymatic-gravimetric method of Prosky et al. (1984). Total carbohydrate was determined by the difference method: 100 - (weight in grams [moisture + ash +protein + total fat + total dietary fiber in $100 \mathrm{~g}$ of food).

\section{Pectin}

Pectin was determined following the Pearson method (Pearson, 1976) and consisted of the neutralization the overall charge of free uronic acid residues by calcium ions causing gelation and precipitation of pectin .The results were expressed in grams of calcium pectate per $100 \mathrm{~g}$ of sample.

\section{Fructose, glucose, and sucrose}

Fructose, glucose, and sucrose were determined according to the method of Feinberg \& Burgner (1992) based on the extraction of sugars from an aqueous medium and determining 
the levels of these sugars by high performance liquid chromatography.

\section{Total energetic value}

The total energy was calculated based on the energy nutrient results obtained using the conversion factors of Atwater, as described by Osborne \& Voogt (1978), considering $4 \mathrm{kcal} / \mathrm{g}$ for carbohydrate, $4 \mathrm{kcal} / \mathrm{g}$ for protein, and $9 \mathrm{kcal} / \mathrm{g}$ for lipids.

\subsection{Bioactive compounds}

\section{Soluble and insoluble dietary fiber}

The values of soluble fiber (SDF) and insoluble fiber (IDF) were obtained by the enzymatic-gravimetric method, according to Prosky et al. (1992). The samples were subjected to the action of a-amylase (Sigma, A-5426), and subsequently protease (Sigma P-3910) and amyloglucosidase (Sigma A-9913). Based on this hydrolysate, the insoluble fiber content was determined by washing in water and acetone and the soluble fiber obtained from the filtrate by precipitation with ethanol $98 \%$ and filtration with ethanol and acetone.

\section{Vitamin C}

Vitamin C was determined according to the method described by Pearson \& Cox (1976), which is based on the reduction of 2.6-dichlorophenol indophenol sodium (ITD) by ascorbic acid. The result was expressed in milligrams of ascorbic acid/100g sample.

\section{Anthocyanins}

The determination of anthocyanins was performed according to the method of Francis (1982). For the extraction, $1 \mathrm{~g}$ of dehydrated pomace was homogenized with a solution of $\mathrm{HCl}(1.5 \mathrm{~N})$ and ethanol $85 \%$. After a period of 24 hours under refrigeration and absence of light, the extracts were filtered and read at $535 \mathrm{~nm}$ using a Coleman 33D spectrophotometer. The results were expressed as $\mathrm{mg}$ of anthocyanins totais $/ 100 \mathrm{~g}$ sample and calculated using the formula: (absorbance $\mathrm{x}$ dilution factor)/98.2.

\subsection{Determination of minerals}

The analyses of minerals were performed at the Laboratory of Water and Soil of the EMBRAPA (Brazilian Agricultural Research Corporation - Tropical Agroindustry), in Fortaleza, Ceará, Brazil. Initially, nitric perchloric acid digestion of the sample was performed.The minerals calcium $(\mathrm{Ca})$, magnesium $(\mathrm{Mg})$, iron $(\mathrm{Fe})$, zinc $(\mathrm{Zn})$, and manganese $(\mathrm{Mn})$ were determined by atomic absorption spectrophotometry using a Perkin Elmer AAnalyst 300 spectrophotometer. The minerals Sodium $(\mathrm{Na})$ and potassium $(\mathrm{K})$ were determined by flame photometry using a flame photometer (Digimed, DM62). Phosphorus (P) and sulfur (S) were determined using a spectrophotometer at a wavelength of $660 \mathrm{~nm}$ for phosphorus and $420 \mathrm{~nm}$ for sulfur. All determinations of these minerals followed the method described by Silva (1999) and were performed in triplicate.

\subsection{Microbiological Analysis}

The microbiological quality of the samples was determined by counting standard Coliforms at $45^{\circ} \mathrm{C}$, Bacillus cereus, and Salmonella, according to the method described by American Public Health Association (2002) and Silva et al. (2001). The results were compared with the standards of the Resolution No. 12, dated January 2, 2001, the National Agency for Sanitary Surveillance in Brazil, which sets standards for the microbiological quality of the flour group: pasta, bakery products and similar products; and starch subgroup: flours, and powdered or flocked starch and cornmeal (Agência Nacional de Vigilância Sanitária, 2001).

\subsection{Toxic potential using Artemia salina sp.}

\section{Preparation of extracts}

From the grape pomace flour, extraction was performed using different solvents using the Soxhlet apparatus as described by the Adolfo Lutz Institute (2008), according to the analytical standards of the Adolfo Lutz Institute. For the extraction, the following solvents were used, hexane (non-polar), ethanol, acetone, and methanol (polar) to obtain a water-soluble extract without interference. The extraction was controlled for $6 \mathrm{~h}$ at $60^{\circ} \mathrm{C}$. The material extracted was concentrated under vacuum using in a rotary evaporator (Fisatom, model 801) at a temperature of $50^{\circ} \mathrm{C}$. After the process, the extracts were subjected to thermostatic bath at a temperature of $60^{\circ} \mathrm{C}$ until there was no trace of solvent. The extracts were stored with protection from light in glass containers until the analysis.

\section{Toxic potential}

The toxic potential of the extracts was determined using the larvae of Artemia salina sp. according to the method described by Meyer et al. (1982) and McLaughlin et al. (1991). The eggs of Artemia salina sp. were hydrated in an aquarium containing synthetic saline water adapted to $12 \mathrm{ppm}$ in ambient temperature around $25^{\circ} \mathrm{C}$. After a period of time of approximately 48 hours, the eggs hatched and gave rise to larvae, which were collected for bioassays. The dilutions of ethanol, acetone, and methanol extracts and a blank test were conducted in synthetic saline, $0.5 \mathrm{~mL}$ of dimethyl sulfoxide concentration (DMSO), to which ten larvae were added in $50 \mathrm{~mL}$ plastic cups. For the negative control, larvae were kept only in synthetic saline. After 24 hours incubation, living and dead larvae were counted to calculate survival percentage, which was used to determine the $\mathrm{LC}_{50}$ (lethal concentration for $50 \%$ of larvae).

\subsection{Statistical analysis}

Analyses were carried out in triplicate. All results were expressed as means \pm standard deviation (SD) using the software Origin $^{\circledR}$ for Windows, version 7.0 (OriginLab, 2002). 


\section{Results and discussion}

\subsection{Characterization of grape pomace flour}

After the pomace sieving process through a sieve using five different mesh openings, the flour particle size was standardized between $0.42 \mathrm{~mm}$ and $0.60 \mathrm{~mm}$ in diameter since the retention of larger amounts of flour occurred in the sieves between 30 and 40 "mesh". The yield relative to the initial raw material, it was found that $1 \mathrm{~kg}$ of grape marc fresh yields approximately $321 \mathrm{~g}$ of processed flour, with yields close to $32 \%$.

\subsection{Physicochemical characterization}

The results of the physicochemical analyses are shown in Table 1 . In addition to low moisture $(3.33 \pm 0.04 \mathrm{~g} / 100 \mathrm{~g})$, the $\mathrm{pH}$ value of the pomace grape flour was below neutral $(3.82 \pm 0.01)$, which led to greater stability hampering the development microorganisms because fungi generally prefer acidic $\mathrm{pH}$ (4.5-5.0) and bacteria prefer near neutral $\mathrm{pH}$ (6.5-7.0). The $\mathrm{pH}$ of grape residue flour are directly correlated with the $\mathrm{pH}$ of fresh grape. Investigating grapes of the variety Benitaka, Pinheiro et al. (2009) observed $\mathrm{pH}$ of 3.65, a value similar to that found in the present study.

The moisture content found in this study are lower than those found by Tangolar et al. (2009) in seeds of seven grape varieties (4.95 to $6.54 \mathrm{~g} / 100 \mathrm{~g}$ ). According to Resolution $\mathrm{N}^{\circ} .263$, dated 2005, 22 September, the National Agency for Sanitary Vigilance (2005), the maximum value of for flours should be $15 \%$. As for acidity, the value found in this study was $0.64 \pm 0.004$ $\mathrm{g}$ of citric acid $/ 100 \mathrm{~g}$. Acidity can determine the quality of the flour under study. With respect to wheat flour, the higher the acidity, the lower its quality, and when it is used as a raw material, it directly affects the final product.

Comparing the values observed in the present study with that of the pure wheat flour, maximum of 3\% (Abud \& Narain, 2009), an adequate pomace grape flour acidity is achieved. The higher acidity values correlate with more significant concentrations of tartaric and malic acids in the skins of grapes (Rizzon \& Miele, 2001). The amount of total dietary fiber $(46.17 \mathrm{~g} / 100 \mathrm{~g})$ was higher than that of the other nutrients, leading to the conclusion that it is as a major component of the raw material of this study, in quantitative terms. This value was

Table 1. Physicochemical analysis of grape pomace (Vitis vinifera L.) flour.

\begin{tabular}{cc}
\hline Parameters $(\%$ dry basis) & Results $($ Mean \pm SD) \\
\hline Moisture $(\mathrm{g} / 100 \mathrm{~g})$ & $3.33 \pm 0.04$ \\
Ash $(\mathrm{g} / 100 \mathrm{~g})$ & $4.65 \pm 0.05$ \\
Total Lipids $(\mathrm{g} / 100 \mathrm{~g})$ & $8.16 \pm 0.01$ \\
Protein $(\mathrm{g} / 100 \mathrm{~g})$ & $8.49 \pm 0.02$ \\
Carbohydrate $(\mathrm{g} / 100 \mathrm{~g})$ & 29.20 \\
Pectin $(\mathrm{g} / 100 \mathrm{~g})$ & $3.92 \pm 0.02$ \\
Frutose $(\mathrm{g} / 100 \mathrm{~g})$ & $8.91 \pm 0.08$ \\
Glucose $(\mathrm{g} / 100 \mathrm{~g})$ & $7.95 \pm 0.07$ \\
Total dietary fiber $(\mathrm{g} / 100 \mathrm{~g})$ & $46.17 \pm 0.80$ \\
Total Calories $(\mathrm{Kcal} / 100 \mathrm{~g})$ & 224 \\
\hline
\end{tabular}

higher than that found in studies that quantified the dietary fiber content of flour residues in grape, 25.62 and $31.66 \mathrm{~g} / 100 \mathrm{~g}$ (Bampi et al., 2010). However, it was higher when compared to the fiber content in green banana flour $(17.98 \mathrm{~g} / 100 \mathrm{~g})$ and wheat flour ( $2.3 \mathrm{~g} / 100 \mathrm{~g}$ ) (Universidade Estadual de Campinas, 2006). Fiber content is related not only to the quantitative but also qualitative aspect since grape pomace fibers are structurally different from those found in other cereals and other fruits since they are associated with polyphenols with antioxidant activity.

With regard to the lipid content, the value found $(8.16 \mathrm{~g} / 100 \mathrm{~g})$ was higher than that reported by Bampi et al. (2010) in flour grape residues $(2.56 \mathrm{~g} / 100 \mathrm{~g})$. The lipids of the grapes are mainly concentrated in its seeds and consist of about $90 \%$ monounsaturated fatty acids, known for their beneficial properties, particularly to the cardiovascular system (Rockenbach et al., 2010).

The amount of protein corresponded to $8.49 \mathrm{~g} / 100 \mathrm{~g}$ of sample analyzed. Higher values $(11 \mathrm{~g} / 100 \mathrm{~g}, 12 \mathrm{~g} / 100 \mathrm{~g}$, and $14 \mathrm{~g} / 100 \mathrm{~g}$ ) were found by Valiente et al. (1995), Llobera \& Cañellas (2007) and Bravo \& Saura-Calixto (1998) in grape residues.

With respect to the carbohydrates, they accounted for 29.20 $\mathrm{g} / 100 \mathrm{~g}$ sample, and fructose was present in the greatest amount $(8.91 \mathrm{~g} / 100 \mathrm{~g})$, followed by glucose $(7.95 \mathrm{~g} / 100 \mathrm{~g})$. There were no significant values for sucrose. Bampi et al. (2010) reported $52.56 \mathrm{~g} / 100 \mathrm{~g}$ values for carbohydrates in Japanese grape flour. Carbohydrates and proteins are essential for human health. Carbohydrates are the body's preferred energy source, and they provide fuel for the central nervous system and for the other organs of the human body. Proteins are required for the growth, development, regeneration and reconstruction of the body and are responsible for the production of antibodies, blood cells, hormones, and enzymes (Cetin et al., 2011).

\subsection{Bioactive compounds}

Vitamin C levels can be considered an index of nutritional quality of foods because its presence demonstrates that other nutrients were probably preserved since vitamin $\mathrm{C}$ is thermolabil. The amount of Vitamin C in grapes is $10.8 \mathrm{mg} / 100 \mathrm{~g}$ edible part, on average (Pinheiro et al., 2009). The grape pomace flour obtained had $26.25 \mathrm{mg}$ ascorbic acid/100g (Table 2). This result was higher than that found by Souza et al. (2012) in the skin of grape Vitis vinifera L. ( 4.9 to $12.2 \mathrm{mg}$ ascorbic acid/100g) and it is significant since the samples were oven heated.

Regarding the content of anthocyanins, the grape pomace flour obtained had $131 \mathrm{mg} / 100 \mathrm{~g}$. This result was higher than that found by Sousa et al. (2011) in fruit waste, with values of $8.4 \mu \mathrm{g} / 100 \mathrm{~g}$ in residues of acerola, and $3.2 \mu \mathrm{g} / 100 \mathrm{~g}$ in guava

Table 2. Bioactive compounds in pomace grape (Vitis vinifera L.) flour.

\begin{tabular}{cc}
\hline Bioactive compounds & Results $($ Mean \pm SD) \\
\hline Vitamin C (mg ascorbic acid/100g) & $26.25 \pm 0.01$ \\
Total anthocyanins $(\mathrm{mg} / 100 \mathrm{~g})$ & $131 \pm 0.4$ \\
Soluble dietary fiber $(\mathrm{g} / 100 \mathrm{~g})$ & $9.76 \pm 0.03$ \\
Insoluble dietary fiber $(\mathrm{g} / 100 \mathrm{~g})$ & $36.40 \pm 0.84$ \\
\hline
\end{tabular}


waste. Anthocyanin pigments are present in the grape skin, and their levels may vary from 30 to $750 \mathrm{mg} / 100 \mathrm{~g}$ fruit, in agreement with the values found in this study (Bridle \& Timberlake, 1997). Rockenbach et al. (2011) found higher values of anthocyanins, ranging from 385.93 to $934.67 \mathrm{mg} / 100 \mathrm{~g} \mathrm{mg} / 100 \mathrm{~g}$, in red grape bagasse Pinheiro (2009) found values of $3.56 \mathrm{mg} / 100 \mathrm{~mL}$ in grape juice at baseline and $1.43 \mathrm{mg} / 100 \mathrm{~mL}$ after 210 days of storage. Levels of anthocyanins in grapes is associated not only with the portion of the fruit analyzed, but they can also be influenced by factors such as cultivar, cultivation method, climatic aspects, and physicochemical factors such as $\mathrm{pH}$ and temperature (Kato et al., 2012).

As for the total dietary fiber, the IDF $79 \%$ (36.4 g/100g) was higher than the SDF, $21 \%$ (9.76 g/100g). The IDF is predominantly composed of cellulose and hemicellulose and lignin (lesser amount). Pectin predominates in the SDF (Bravo \& Saura-Calixto, 1998).

In this study, we found $3.92 \pm 0.02 \mathrm{~g} / 100 \mathrm{~g}$ of pectin, a value close to a similar study (2.3-4.4 g/100g) (Bravo \& SauraCalixto, 1998). Higher values $(6.2 \mathrm{~g} / 100 \mathrm{~g})$ were found by Llobera \& Canellas (2007) in grape by-products. According to Mildner-Szkudlarz et al. (2013), the proportion of SDF and IDF in the diet should be between 1:4 and 1:3. Soluble fiber reduces the risk of heart diseases and lowers levels of cholesterol triglycerides, and glucose in the blood (MildnerSzkudlarz et al., 2013; Marlett et al., 2002). The insoluble fraction has a positive influence on the colon (Stampanoni, 1998). According to Schneeman (1987), 30-50\% SDF and 50-70\% IDF are considered to be well-balanced proportions for maximum health benefits. Thus, the flour obtained from grape pomace, providing $79 \% \mathrm{IDF}$ and $21 \% \mathrm{SDF}$, is a good sources of DF. According to Pérez-Jiménez et al. (2008), grape DF significantly reduced the lipid profile and blood pressure, these effects were significantly greater than those caused by other DFs such as oat fiber or psyllium, probably owing to the combined effect of DF and antioxidants.

\subsection{Minerals}

According to the results of the mineral analysis shown in Table 3, iron, potassium, zinc, manganes, and calcium were present in higher concentrations. There were no significant values for copper. Potassium levels higher than those of sodium can lead to a mineral balance that favors hypertension control. A

Table 3. Composition of minerals (mg/100g) in grape pomace (Vitis vinifera L.) flour.

\begin{tabular}{cc}
\hline Minerals & Results (Mean \pm SD) \\
\hline Calcium & $0.44 \pm 0.715$ \\
Magnesium & $0.13 \pm 0.255$ \\
Sodium & $0.044 \pm 0.056$ \\
Potassium & $1.40 \pm 0.313$ \\
Iron & $18.08 \pm 0.03$ \\
Manganese & $0.817 \pm 0.550$ \\
Phosphorus & $0.183 \pm 0.255$ \\
Sulfur & $0.089 \pm 0.336$ \\
Zinc & $0.98 \pm 0.702$ \\
\hline
\end{tabular}

diet rich in potassium lowers blood pressure and consequently the risk of morbidity and mortality due to cardiovascular diseases; in addition, potassium intake can decrease urinary calcium excretion and consequently reduce the risk of developing osteoporosis (Cetin et al., 2011).

Comparing with Dietary Reference Intakes (DRI) (National Academy of Sciences, 2011), the amount of iron found in this study $(18.08 \mathrm{mg} / 100 \mathrm{~g})$ supplies the adult daily requirements for iron $(8 \mathrm{mg} /$ day for men and 8 to $18 \mathrm{mg}$ /day for women). For zinc, the recommended daily intake is $11 \mathrm{mg}$ for men and $8 \mathrm{mg}$ for women. The amount of zinc found was $0.98 \mathrm{mg} / 100 \mathrm{~g}$. These minerals are considered essential for the human body. Iron, among other functions, is associated with the production of blood cells, and zinc is essential for the immune system. Both nutrients are also considered potent antioxidants. Lachman et al. (2013), in a study on minerals present in grape seed found lower values of calcium $(0.27 \mathrm{mg} / 100 \mathrm{~g})$, iron $(4.54 \mathrm{mg} / 100 \mathrm{~g})$, and phosphorus $(0.02 \mathrm{mg} / 100 \mathrm{~g})$ and higher values of manganese $(1.45 \mathrm{mg} / 100 \mathrm{~g})$. However, similar values were reported for magnesium (0.10 mg/100 g), sodium (0.042 mg/100g), and zinc $(1.1 \mathrm{mg} / 100 \mathrm{~g})$.

Rizzon \& Miele (2012), investigating minerals in grape juice, found higher values of sodium $(0.067 \mathrm{mg} / 100 \mathrm{~g})$, potassium (129.5 mg/100g), phosphorus ( $10.5 \mathrm{mg} / 100 \mathrm{~g})$, and magnesium $(8.78 \mathrm{mg} / 100 \mathrm{~g})$, but lower values of iron $(0.14 \mathrm{mg} / 100 \mathrm{~g})$.

\subsection{Microbiological quality}

The results shown in Table 4 indicate that the grape pomace flour has microbiological characteristics acceptable for human consumption, which is consistent with the standards recommended by the Resolution $\mathrm{N}^{\text {o. }} 12$ of January 2, 2001, the National Agency for Sanitary Surveillance (2001). Possibly, the satisfactory results of microbiological parameters are due to the fact that the grape flour does not provide favorable conditions for microbial growth, such as low moisture and $\mathrm{pH}$ lower than 4 .

\subsection{Toxic potential using the larvae of Artemia salina sp.}

Meyer et al. (1982) established the relationship between the degree of toxicity and median lethal dose, $\mathrm{LC}_{50}$ of plant extracts against larvae of Artemia salina sp.; values above $1000 \mu \mathrm{g} / \mathrm{mL}$ are considered nontoxic. All extracts were evaluated against their toxicity to Artemia salina sp. and were considered nontoxic since all microcrustaceans remained alive. Nascimento et al. (2008) studied toxicity in three species of medicinal plants of the genus Phyllanthus and reported absence of toxicity only in the species P.amarus. Leite et al. (2009) found that hexane

Table 4. Microbiological Analysis of grape pomace (Vitis vinifera L.) flour.

\begin{tabular}{|c|c|c|}
\hline Microorganism & Result & Tolerance $^{*}$ \\
\hline Salmonella (in 25g) & Absent & Absent \\
\hline Fecal Coliforms (MPN/g) ${ }^{* *}$ & $<3$ & $10^{2}$ \\
\hline Bacillus cereus $(\mathrm{CFU} / \mathrm{g})^{* * *}$ & $<100$ & $3 \times 10^{3}$ \\
\hline
\end{tabular}


extract from avocado seeds showed toxicity to Artemia salina $\left(\mathrm{LC}_{50}\right.$ of $\left.2.37 \mathrm{mg} / \mathrm{mL}^{-1}\right)$.

The absence of toxicity may be an advantage to a possible use of this extract in the development of new herbal medicines and for human use.

\section{Conclusions}

This study is the first characterization of grape pomace grown in the state of Piaui. The results show that it is an important source of nutrients and compounds with functional properties. The grape pomace flour obtained showed low and $\mathrm{pH}$ below neutral, which can help prevent growth of pathogenic microorganisms. The amount of total dietary fiber is quantitatively greater compared to that of carbohydrates, proteins, and lipids, indicating that this residue could be included in the daily diet as a source of fiber and food supplement. Regarding compounds with functional properties, the results show that grape pomace may be a potential source of bioactive compounds, especially higher concentration of insoluble fibers in relation to the soluble fraction, and significant amounts of vitamin $\mathrm{C}$ and anthocyanins. As for minerals, iron, potassium, zinc, calcium, and manganese are present in higher concentrations. Furthermore, the results of this study suggest that the flour produced from grape pomace, which is environmentally appropriate and easy to obtain, may be a potential food ingredient in the daily diet or as a nutritional supplement. The microbiological and toxicity bioassays show that the grape pomace evaluated was not contaminated and it was therefore considered and were considered. It is suggested, however, that further studies should be conducted on this residue, for example, to evaluate the presence of other bioactive compounds, including the evaluation of the antioxidant activity of the phenolic compounds and fatty acid composition in the seeds of this residue.

\section{Acknowledgements}

The authors are grateful for the financial support provided by $\mathrm{CNPq} / \mathrm{CAPES}$ (National Council for Scientific and Technological Development - Brazil), to the CODEVASF (São Francisco and Parnaíba Valley Development Company ) that provided samples of grape, and to EMBRAPA (Brazilian Agricultural Research Corporation - Tropical Agroindustry), for the contribution to the mineral analysis.

\section{References}

Abud, A. K. S., \& Narain, N. (2009). Incorporação da farinha de resíduo do processamento de polpa de fruta em biscoitos: uma alternativa de combate ao desperdício. Brazilian Journal of Food Technology, 12(4), 257-265. http://dx.doi.org/10.4260/BJFT2009800900020

Agência Nacional de Vigilância Sanitária (2001). Aprova Regulamento Técnico sobre Padrões de qualidade microbiológica de alimentos para o grupo de farinhas, massas alimentícias, produtos para panificação e similares; subgrupo amidos, farinhas, féculas e fubá, em pó ou flocados (Resolução-RDC no 12, de 02 de janeiro de 2001). Retrieved from http://portal.anvisa.gov.br.
Agência Nacional de Vigilância Sanitária (2005). Aprova o Regulamento Técnico para produtos de cereais, amidos, farinhas e farelos (Resolução-RDC no 263, de 22 de setembro de 2005). Retrieved from http://portal.anvisa.gov.br.

Ahmad, S. M., \& Ali Siahsar, B. (2011). Analogy of physicochemical attributes of two grape seeds cultivar. Ciencia e Investigación Agraria, 38(2), 291-301. http://dx.doi.org/10.4067/S071816202011000200014

American Public Health Association - APHA. (2002). In F. P. Downes \& K. Ito (Eds.), Compendium of methods for the microbiological examination of foods. Washingthon: APHA.

Andrade Júnior, A. S., Tonietto, J., Bastos, E. A., \& Conceição, M. A. F. (2005). Classificação climática e regionalização do semi-árido do Estado do Piauí sob cenários pluviométricos distintos. Revista Ciência Agronômica. 36(2), 143-151.

Araújo, M. G. F., Cunha, W. R., \& Veneziani, R. C. S. (2010). Estudo fitoquímico preliminar e bioensaio toxicológico frente a larvas de Artemia salina Leach. de extrato obtido de frutos de Solanum lycocarpum A. ST.-Hill (Solanaceae). Revista de Ciências Farmacêuticas Básica e Aplicada, 31(2), 205-209.

Association of Official Analytical Chemist - AOAC. (1995). Official Methods of Analysis (16th ed.). Gaithersburg: AOAC.

Bampi, M., Bicudo, M. O. P., Fontoura, P. S. G., \& Ribani, R. F. (2010). Composição centesimal do fruto, extrato concentrado e da farinha da uva-do-japão. Ciência Rural, 40(11), 2361-2367. http://dx.doi. org/10.1590/S0103-84782010001100018

Brasil, Ministério da Agricultura, Pecuária e Abastecimento. Regulamento Técnico de Identidade e Qualidade para classificação de uva fina de mesa (Instrução Normativa ${ }^{\circ} 01$ de 01 de fevereiro de 2000). Diário Oficial da República Federativa do Brasil. Seção 1, p. 2.

Brasil, Ministerio do Meio Ambiente. (2011). Plano nacional de residuos solidos. Brasília: Ministerio do Meio Ambiente.

Bravo, L., \& Saura-Calixto, F. (1998). Characterization of dietary fiber and the in vitro indigestible fraction of grape pomace. American Journal of Enology and Viticulture, 49(2), 135-141.

Bridle, P., \& Timberlake, C. F. (1997). Anthocyanins as natural food colours: selected aspects. Food Chemistry, 58(12), 103-109. http:// dx.doi.org/10.1016/S0308-8146(96)00222-1

Burin, V. M., Falcão, L. D., Gonzaga, L. V., Fett, R., Rosier, J. P., \& Bordignon-Luiz, M. T. (2010). Colour, phenolic content and antioxidant activity of grape juice. Ciência e Tecnologia de Alimentos, 30(4), 1027-1032. http://dx.doi.org/10.1590/S010120612010000400030

Bussmann, R. W., Malca, G., Glenna, A., Sharon, D., Nilsen, B., Parris, B., Duboce, D., Ruiz, D., Saleda, J., Mertinez, M., Carillo, L., Walker, K., Kuhlman, A., \& Townesmith, A. (2011). Toxicity of medicinal plants used in traditional medicine in Northern Peru. Journal of Ethnopharmacology, 137(1), 121-140. PMid:21575699. PMCid:PMC3159793. http://dx.doi.org/10.1016/j.jep.2011.04.071

Bustamante, M. A., Moral, R., Paredes, C., Pérez-Espinosa, A., Moreno-Caselles, J., \& Pérez-Murcia, M. D. (2008). Agrochemical characterisation of the solid by-products and residues from the winery and distillery industry. Waste Management, 28(2), 372-380. PMid:17433659. http://dx.doi.org/10.1016/j.wasman.2007.01.013

Camargo, U. A., Tonietto, J., \& Hoffmann, A. (2011). Progressos na Viticultura Brasileira. Revista Brasileira de Fruticultura E, 144-149. http://dx.doi.org/10.1590/S0100-29452011000500017

Cetin, E. S., Altinöz, D., Tarçan, E., \& Baydar, N. G. (2011). Chemical composition of grape canes. Industrial Crops and Products, 34(1), 994-998. http://dx.doi.org/10.1016/j.indcrop.2011.03.004 
Coombe, B. G. (1987). Influence of temperature on composition and quality of grapes. Acta Horticulturae, 206, 23-35.

Costacurta, A., \& Roselli, G. (1980). Critères climatiques et edaphiques pour l'établissement des vignobles. Le Bulletin de l'Organisation Internationale de la Vigne et du Vin, 53(596), 783-786.

Deng, Q., Penner, M. H., \& Zhao, Y. (2011). Chemical composition of dietary fiber and polyphenols of five different varieties of wine grape pomace skins. Food Research International, 44, 2712-2720. http://dx.doi.org/10.1016/j.foodres.2011.05.026

Devesa-Rey, R., Vecino, X., Varela-Alende, J. L., Barral, M. T., Cruz, J. M., \& Moldes, A. B. (2011). Valorization of winery waste vs. the costs of not recycling. Waste Management, 31, 2327-2335. PMid:21752623. http://dx.doi.org/10.1016/j.wasman.2011.06.001

Feinberg, M., \& Burgner, E. (1992). Determination of mono and disaccharides in foods by interlaboratory study: quantification of Bias components for liquid chromatography. Journal of AOAC International, 75(3), 443-464.

Food and Agriculture Organization of the United Nations - FAO. (2010). FAO Statistical Databases. Retrieved from http://faostat. fao.org.

Francis, F. J. (1982). Analysis of anthocyanins. In P. Markakis, Anthocyanins as food colors. New York: Academic Press. p. 181-207. PMid:6764769 PMCid:PMC272050.

Instituto Adolfo Lutz - IAL. (2008). In O. Zenebon, N. S. Pascuet \& P. Tiglea (Coords.), Métodos físico-químicos para análise de alimentos (4. ed.). São Paulo: IAL.

Instituto Brasileiro de Geografia e Estatística - IBGE. (2013). Produção agrícola municipal. Brasília: IBGE. Retrieved from http: www.sidra. ibge.gov.br/bda/tabela.

Jiménez, C. D. C., Flores, C. S., He, J., Tian, Q., Schwartz, S. J., \& Giusti, M. M. (2011). Characterization and preliminary bioactivity determination of Berberis boliviana Lechler fruit anthocyanins. Food Chemistry, 128(3), 717-724. http://dx.doi.org/10.1016/j. foodchem.2011.03.094

Kato, C. G., Tonhi, C. D., \& Clemente, E. (2012). Antocianinas de uvas (Vitis vinífera L.) produzidas em sistema convencional. Revista Brasileira de Tecnologia Agroindustrial, 6(2), 809-821. http://dx.doi. org/10.3895/S1981-36862012000200007

Lachman, J., Hejtmánkova, A., Hejtmánkova, K., Hornickova, S., Pivec, V., Skala, O., Dedina, M., \& Pribyl, J. (2013). Towards complex utilisation of winemaking residues:Characterisation of grape seeds by total phenols, tocols and essentialelements content as a byproduct of winemaking. Industrial Crops and Products, 49, 445-453. http://dx.doi.org/10.1016/j.indcrop.2013.05.022

Lachumy, S. J. T., Sasidharan, S., Sumathya, V., \& Zurainia, Z. (2010). Pharmacological activity, phytochemical analysis and toxicity of methanol extract of Etlingera elatior (torch ginger) flowers. Asian Pacific Journal of Tropical Medicine, 3(10), 769-774. http://dx.doi. org/10.1016/S1995-7645(10)60185-X

Leite, J. J. G., Brito, E. H. S., Cordeiro, R. A., Brilhante, R. S. N., Sidrim, J. J. C., Bertini, L. M., Morais, S. M., \& Rocha, M. F. G. (2009). Chemical composition, toxicity and larvicidal and antifungal activities of Persea americana (avocado) seed extracts. Revista da Sociedade Brasileira de Medicina Tropical, 42(2), 110-113. PMid:19448924. http://dx.doi.org/10.1590/S0037-86822009000200003

Llobera, A., \& Cañellas, J. (2007). Dietary fibre content and antioxidant activity of Manto Negro red grape (Vitis vinifera): pomace and stem. Food Chemistry, 101(2), 659-666. http://dx.doi.org/10.1016/j. foodchem.2006.02.025
Marlett, J. A., McBurney, M. I., \& Slavin, J. L. (2002). Position of the American Dietetic Association: health implications of dietary fiber. Journal of the American Dietetic Association, 102(7), 993-1000. http://dx.doi.org/10.1016/S0002-8223(02)90228-2

McLaughlin, J. L., Chang, C. J., \& Smith, D. L. (1991). Studies in natural products chemistry. Amsterdam: Elsevier.

Meyer, B. N., Ferrigni, N. R., Putnam, L. B., Jacobsen, L. B., Nichols, D. E., \& McLaughlin, J. L. (1982). Brine shrimp: a convenient general bioassay for active plant constituents. Journal of Medicinal Plant Research, 45, 31-34. http://dx.doi.org/10.1055/s-2007-971236

Mildner-Szkudlarz, S., Bajerska, J., Zawirska-Wojtasiaka, R., \& Góreckac, D. (2013). White grape pomace as a source of dietary fibre and polyphenols and its effect on physical and nutraceutical characteristics of wheat biscuits. Journal of the Science of Food and Agriculture, 93, 389-395. PMid:22806270. http://dx.doi.org/10.1002/ jsfa. 5774

Nascimento, J. E., Melo, A. F. M., Lima e Silva, T. C., Veras Filho, J., Santos, E. M., Albuquerque, U. P., \& Amorim, E. L. C. (2008). Estudo fitoquímico e bioensaio toxicológico frente a larvas de Artemia salina Leach. de três espécies medicinais do gênero Phyllanthus (Phyllanthaceae). Revista de Ciências Farmacêuticas Básica e Aplicada, 29(2), 145-150.

National Academy of Sciences. (2001). Dietary Reference Intakes for Vitamin A, Vitamin K, Arsenic, Boron, Chromium, Copper, Iodine, Iron, Manganese, Molybdenum, Nickel, Silicon, Vanadium, and Zinc. Washington: National Academy Press.

OriginLab. (2002). Origin ${ }^{\circledR}$ for Windows, version 7.0. USA: OriginLab Corporation.

Osborne, D. R., \& Voogt, T. P. (1978). The analysis in nutrient in foods. London: Academic. p. 156-158.

Pearson, D. (1976). Chemical analysis of foods (7th ed.). Livingstone: Churchill. p. 7-11.

Pearson, D., \& Cox, H. E. (1976). The chemical analysis of foods. New York: Chem. Publ.

Pérez Jiménez, J., Serrano, J., Tabernero, M., Arranz, S., Díaz-Rubio, M. E., García-Diz, L., Goñi, I., \& Saura-Calixto, F. (2008). Effects of grape antioxidant dietary fiber in cardiovascular disease risk factors. Nutrition, 24(7-8), 646-653. PMid:18485668. http://dx.doi. org/10.1016/j.nut.2008.03.012

Pinheiro, E. S., Costa, J. M. C., Clemente, E., Machado, P. H. S., \& Maia, G. A. (2009). Estabilidade físico-química e mineral do suco de uva obtido por extração a vapor. Revista Ciência Agronômica, 40(3), 373-380.

Pontes, P. R. B., Santiago, S. S., Szabo, T. N., Toledo, L. P., \& Gollücke, A. P. B. (2010). Atributos sensoriais e aceitação de sucos de uva comerciais. Ciência e Tecnologia de Alimentos, 30(2), 313-318.

Prosky, L., Asp, N. G., Furda, I., DeVries, J. W., Schweizer, T. F., \& Harland, B. F. (1984). Determination of total dietary fiber in foods, food products and total diets: Interlaboratory Study. Journal of The Association Official Analytical Chemists, 67(6), 1044-1052.

Prosky, L., Asp, N. G., Schweizer, T. F., DeVries, J. W., \& Furda, I. (1992). Determination of insoluble and soluble dietary fibers in foods, and food products. Journal of The Association Official Analytical Chemists, 75(12), 360-367.

Rizzon, L. A., \& Miele, A. (2001). Concentração de ácido tartárico dos vinhos da serra gaúcha. Ciência Rural, 31(5), 893-895. http://dx.doi. org/10.1590/S0103-84782001000500027

Rizzon, L. A., \& Miele, A. (2012). Analytical characteristics and discrimination of Brazilian commercial grape juice, nectar, and 
beverage. Ciência e Tecnologia de Alimentos, 32(1), 93-97. http:// dx.doi.org/10.1590/S0101-20612012005000015

Rockenbach, I. I., Gonzaga, L. V., Rizelio, V. M., Gonçalves, A. E. S. S., Genovese, M. I., \& Fett, R. (2011). Phenolic compounds and antioxidant activity of seed and skin extracts of red grape (Vitis vinifera and Vitis labrusca) pomace from Brazilian winemaking. Food Research International, 44, 897-901. http://dx.doi. org/10.1016/j.foodres.2011.01.049

Rockenbach, I. I., Rodrigues, E., Gonzaga, L. V., \& Fett, R. (2010). Composição de ácidos graxos de óleo de semente de uva (Vitis vinifera L. e Vitis labrusca L.). Brazilian Journal of Food Technology, IIISSA.

Rockenbach, I. I., Silva, G. L., Rodrigues, E., Gonzaga, L. V. \& Fett, R. (2007). Atividade antioxidante de extratos de bagaço de uva das variedades Regente e Pinot Noir (Vitis vinifera). Revista do Instituto Adolfo Lutz, 66(2), 158-163.

Rockenbach, I. I., Silva, G. L., Rodrigues, E., Kuskoski, E. M., \& Fett, R. (2008). Influência do solvente no conteúdo total de polifenóis, antocianinas e atividade antioxidante de extratos de bagaço de uva (Vitis vinifera) variedades Tannat e Ancelota. Ciência e Tecnologia de Alimentos, 28(Supl.), 238-244. http://dx.doi.org/10.1590/S010120612008000500036

Rotava, R., Zanella, I., Silva, L. P., Manfron, M. P., Ceron, C. S., Alves, S. H., Karkow, A. K., \& Santos, J. P. A. (2009). Atividade antibacteriana, antioxidante e tanante de subprodutos da uva. Ciência Rural, 39(3), 941-944. http://dx.doi.org/10.1590/S0103-84782009000300051

Ruiz, V. S. (2011). Avances em viticultura em el mundo. Revista Brasileira de Fruticultura, E, 131-143. http://dx.doi.org/10.1590/ S0100-29452011000500016
Schneeman, B. O. (1987). Soluble vs. insoluble fiber different physiological responses. Food Technology, 47, 81-87.

Silva, F. C. (1999). Manual de análises químicas de solos, plantas e fertilizantes. Brasília: Embrapa Comunicação para Transferência e Tecnologia.

Silva, N., Junqueira, V. C. A., \& Silveira, N. F. A. (2001). Manual de métodos de análises microbiológicas de alimentos (2. ed.). São Paulo: Livraria Varela.

Sousa, M. S. B., Vieira, L. M., Silva, M. J. M., \& Lima, A. (2011). Caracterização nutricional e compostos antioxidantes em resíduos de polpas de frutas tropicais. Ciência e Agrotecnologia, 35(3), 554559. http://dx.doi.org/10.1590/S1413-70542011000300017

Souza, A. V., Gomes, G. P., Vieira, M. R. S., Vieites, R. L., \& Lima, G. P. P. (2012). Avaliação de antioxidantes em casca de vitis sp. Revista Alimentus, 2(2), 10-19.

Stampanoni, K. C. R. (1998). Basic flavour descriptive language. Przem. Spoż, 4, 36-39.

Tangolar, S. G., Ozogul, Y., Tangolar, S., \& Torun, A. (2009). Evaluation of fatty acid profiles and mineral content of grape seed oil of some grape genotypes. International Journal of Food Sciences and Nutrition, 60(1), 32-39. PMid:17886077. http://dx.doi. org/10.1080/09637480701581551

Universidade Estadual de Campinas - UNICAMP. (2006). Tabela brasileira de composição de alimentos - TACO (versão 2, 2. ed.). Campinas: UNICAMP/NEPA. Retrieved from http:// unicamp.br/nepa/taco/tabela.php?ativo=tabela.

Valiente, C., Arrigoni, E., Esteban, R. M., \& Amado, R. (1995). Grape pomace as a potencial food fiber. Journal of Food Science, 60(4), 818-820. http://dx.doi.org/10.1111/j.1365-2621.1995.tb06237.x 